\title{
PSYCHOLOGICAL ORIENTATION OF THE ART OF METAMODERNISM
}

УДК 159.9: 7.01

DOI https://doi.org/10.32843/2663-

5208.2020.19.9

\section{Дєніжна С.О.}

к.пед.н.,

доцент кафедри психології, педагогіки та соціології

Університет державної фріскальної служби України

\section{Сова М.O.}

д.пед.н.,

профресор кафедри музичного

мистецтва

Кримський університет культури, мистецтв і туризму у статті обґ́рунтовується актуальність дослідження проблеми психологічної спрямованості мистецтва модернізму, необхідність вирішення якої зумовлена потребою українського суспільства в подоланні духовної кризи, переосмисленні художніх цінностей та орієнтирів культурно-цивілізаційного розвитку.

Мema cтатmі - розкрити психологічну спрямованість мистецтва метамодернізму, визначити його чіннісні орієнтири та рівні розвитку, висвітлити механізми духовного збагачення особистості та суспільства.

У змісті статті розкриваються характерні ознаки мистеитва метамодернізму та його відмінності від художньої творчості епохи модернізму та постмодернізму. Здійснюється диференціація психологічної спрямованості мистецтва метамодернізму за рівнями: психосрізіологічним, конкретно-психологічним, соціально-психологічним, фрілософрсько-психологічним.

Результати дослідження свідчать про те, що глибинний психологізм мистецтва метамодернізму $є$ його визначальною ознакою, яка характеризується спрямованістю на: художнє відображення трансцендентного та іманентного начал у внутрішньому світі особистості; розширення срери свідомості й актуалізацію несвідомих прочесів; розкриття «граничних» психологічних станів особистості, що виникають на межі раціонального та ірраціонального; заглиблення у сферу ірреальності, ілюзорності та місрічності; досягнення свободи творчого самовираження; спонукання до розуміння смислу життя.

У висновках відзначається, що психологічна спрямованість метамодернізму передбачає: поринання у глибини емоційної сфрери особистості на межі їі граничних можливостей; злиття реальності й віртуальності в художніх уявленнях; створення проєктів майбутнього життя. Багаторівнева спрямованість мистецтва метамодернізму сприяє інтегрованому сприйняттю художнього образу світу крізь призму рефрлексивних актів свідомості та підсвідомості, переосмисленню духовних цінностей мистецтва, спонукає особистість до перетворень соціокультурної дійсності.

Ключові слова: метамодернізм, психологічна спрямованість, рівні психологічної спрямованості метамодернізму, механізми психологічного впливу мистецтва, свідомі та несвідомі процеси.
In the statistic, the relevance of the preliminaries of the problem of psychological directing of art to modernism, the need for revision, which is summed up by the need for Ukrainian suspension in the region of the spiritual crisis, is determined. reappraisal of artistic values and development of cultural and civilization development.

Meta statistic is the psychological recognition of the directness of the mystery to metamodernism, due to the importance of its value and development, the visibility of the mechanisms of spiritual development of the specialness of that suspension.

In the context of statistics, there are characteristic signs of a mystery of metamodernism and of the imagination of artistic creativity of the era of modernism and postmodernism. There is a differentiation of psychological directing of the mystery of metamodernism behind the equals: psychophysiological, specifically psychological, social and psychological, philosophical and psychological. The results of the preliminaries inform about those, that the Glybinny psychology of the mystery is metamodernism and its initial familiarity, which is characterized by directing to: the artistic representation of the transcendent and immanent began in the inner light; expansion of the scope of evidence and actualization of unrelated processes; the development of "borderline" psychological standards of a specialty, which are found on the boundary between the rational and the rational; drowning in the sphere of reality, illusion and myth; reaching the freedom of creative self-expression; sponukannya to the understanding of life.

In visnovka, it is important that the psychological directing of the universal phenomenon to the metamodernism of transmission is: porous in the world of the social sphere of particularity at the boundary of the boundary possibilities; the representation of the psychological standards of the wicked people in the situations of widespread action, the development of the projects of life. See, how the bagator is to direct the mystery of the metamodernism of the perception of the integration of the artistic image through the prism of reflexive acts in the context of the imagination and perception, the reassessment of the mystical values.

Key words: metamodernism, psychological directness, equal psychological directness to metamodernism, mechanisms of psychological injecting mystery, witness and unseen processes.
Постановка проблеми. У період глибокої духовної кризи, яку переживає Україна, виникає потреба у подоланні тих «бар'єрів», що призводять до відставання держави від світових тенденцій культурно-цивілізаційного розвитку. Негативні наслідки соціальних потрясінь і складної соціокультурної ситуації, яка склалася у країні, зумовлюють необхідність вивчення психологічних проблем духовного життя суспільства, переосмислення цінностей українського суспільства. У зв'язку з цим значно зростає роль психології мистецтва. Психологічна спрямованість художньої творчості епохи метамодернізму зорієнтована на розвиток культури українського суспільства в контексті загальнолюдських цінностей європейської та світової цивілізації, здійснення психологічного впливу на збагачення внутріш- 
нього світу особистості, її самовизначення та творчу самореалізацію в сучасному соціокультурному просторі.

Зростає науковий інтерес дослідників до цінностей мистецтва метамодернізму як аксіологічної бази для виходу сучасного суспільства здуховної кризи, здійсненняперетвореньусфері свідомості людей, розуміння й узгодження альтернативних позицій, розробки та реалізації творчих «проєктів майбутнього».

Будучи своєрідною духовною скарбницею суспільства, мистецтво метамодернізму відіграє важливу роль у вдосконаленні психологічної сфери як окремої особистості, так і суспільства загалом. Світ муз звертається до особистості в усій іï повноті, впливає на людину як на «живе» ціле, на різні «поверхи» психіки - на емоції та інтелект, на глибини підсвідомості та вершини самосвідомості.

У цьому контексті на увагу заслуговують художні концепції, зорієнтовані на заглиблення в індивідуально-особистісні прояви свідомості людини за реальних умов соціокультурної дійсності. Тому актуальності набуває дослідження проблеми психологічної спрямованості мистецтва метамодернізму, вивчення психологічних орієнтирів художньої діяльності в контексті соціокультурних реалій.

Аналіз наукових досліджень і публікацій показав, що у вирішенні проблеми психологічної спрямованості мистецтва метамодернізму вагомого значення набувають наукові надбання представників психоаналітичної теорії 3. Фройда, К. Юнга. Концептуальні положення психоаналізу є пріоритетними орієнтирами розвитку сучасного мистецтва. На них ґрунтується психологічний зміст художніх творів, тлумачення їх ціннісного смислу та інтерпретація. Увага митців зосереджується на зануренні у глибини емоційної сфери особистості, що, у свою чергу, сприяє актуалізації несвідомих процесів, досягненню творчої свободи, художньому відтворенню спогадів про нереалізовані бажання.

Психологічна спрямованість метамодернізму, що передбачає звернення до експресивного вираження почуттів людини з позицій психоаналізу, упередження змін, які асоціюються зі структурою цих почуттів, простежується у кінофільмах У. Андерсона, М. Джулії, C. Джонса; в музичних композиціях груп Arcade Fire, Bill Calahan, Future Islands, поезії Дж. Вагнер, С. Коллінз, зображальному мистецтві О. Еліассона, П. Дойга, квазімістичному мультимедійному проєкті New Hive offerings М. Бродер.

Психоаналітичний напрям розвитку метамодернізму притаманний для таких видів художньої творчості, як: перфоманс, театр абсурду, сучасний танець (contemporary dance, хіп-хоп, тектонік), імпровізаційні композиції.
У контексті нашого дослідження слід відзначити нові тенденції розвитку сучасного мистецтва, окреслені в «Маніфесті метамодернізму» Л. Тьорнер. У положеннях цієї праці метамодернізм характеризується як мінливий стан пошуків множинності несумірних і невловимих горизонтів між (і за межами) іронією та щирістю, наївністю й обізнаністю, релятивізмом та істиною, оптимізмом і сумнівом [4].

У вітчизняному науковому знанні психологічні явища мистецтва метамодернізму досліджували Д. Бакіров і Д. Дроздовський [1; 3].

Як зазначає Д. Дроздовський, у ланцюжку подій, відображених у творах метамодерністського мистецтва, центральною ланкою є межова ситуація, вихід із якої можна знайти, якщо використати інтуїтивізм і логіку, знання й віру, реальність і підсвідоме, наукові технології та людське відчуття. Тим самим у сучасному мистецтві відбувається перехід до нового розуміння емоційності, оригінального тлумачення «естетики довіри», психологічного виміру мистецької культури, а отже, до метамодернізму.

З огляду на викладені теоретичні положення зазначимо, що як самостійний предмет дослідження проблема, яка розглядається, залишається неповною мірою вивченою в науковій літературі. Недостатньо розкриті психологічні «бар'єри», які перешкоджають відходу від історично складених і традиційно використаних у художній практиці канонів, норм і правил академічного мистецтва, що, відповідно, потребує виявлення психологічних механізмів мінімізації тих складнощів, які обмежують прояви свободи самовираження особистості у процесі художньої творчості. Тож актуальною стає проблема дослідження психологічної спрямованості мистецтва метамодернізму та розуміння його ціннісного смислу, розкриття нових засобів психологічного впливу на внутрішній світ особистості та духовне життя сучасного суспільства.

Мета статті - розкрити особливості психологічної спрямованості мистецтва метамодернізму, визначити його ціннісні орієнтири та рівні розвитку, висвітлити механізми духовного збагачення особистості та суспільства.

Виклад основного матеріалу дослідження. Сучасне мистецтво метамодернізму є різноманітним, динамічним і мінливим художнім простором, у якому поєднуються традиції та новації, досягається плюралізм філософсько-естетичних, культурологічних і психологічних позицій, відбувається переосмислення цінностей і перегляд естетичних ідеалів.

Відзначимо, що вперше поняття «мета-

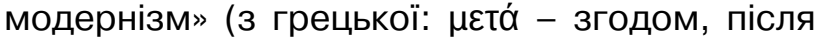
+ англ: modern) використали нідерландські філософи Робін Ван ден Аккер і Тімотей Вермюлен (2010 р.) у «Нотатках про метамодер- 
нізм» (Noteson Metamodernism), які тлумачили цю дефініцію як «коливання» між модернізмом і постмодернізмом [2].

У сучасному значенні метамодернізм розглядається як комплекс здобутків мистецтва, культури, естетики та філософії, що утворився завдяки альтернативній реакції на постмодернізм і характеризується невизначеністю позицій щодо протиставлених аспектів модернізму та постмодернізму. Метамодернізм покликаний відобразити в мистецтві ті зміни, що відбуваються в сучасній культурі, яка розвивається в іншому напрямі, ніж постмодернізм із притаманними йому деструкцією, іронією, стилізацією, релятивізмом, нігілізом і запереченням загальних концепцій.

На противагу постмодернізму, для метамодернізму характерним $€$ прагнення зрозуміти смисл і поступовий рух розвитку культури, повернення до загальних концепцій та універсальної істини, експресивне вираження почуттів, відродження щирості, надії та романтичних тенденцій. Представники метамодернізму намагаються відобразити коливання між іронією та щирістю, конструкцією та реконструкцією, апатією й ентузіазмом, соціальним станом звичайної людини та досягненням стану трансцендентності.

Порівняльний аналіз особливостей і психологічної спрямованості мистецтва модернізму, постмодернізму та метамодернізму дозволяє зазначити, що: а) для модернізму характерними $€$ проголошення радикальних ідей і пошук оригінальних способів їх рішення, універсалізація, позбавлення від трансцендентного; б) для постмодернізму властивими $€$ плюралізм, визнання різних позицій, напрямів, стилів і рефлексія над ними, комбінування елементів мистецтва минулого й теперішнього часу; в) для метамодернізму притаманним $€$ розуміння всіх протилежностей між модернізмом і постмодернізмом як складових частин загальної істини, урівноваження у правах масової та елітарної культури, стирання граней між художньою текстуальністю та реальністю.

Розбіжність між постмодернізмом і метамодернізмом полягає також у тому, що для першого художнього напряму характерною $\epsilon$ гра з читачем, і ми розуміємо, що це саме гра, а для другого властивим $€$ сприйняття гри як реальності, заміщення правил реальності. Ознаки парадоксу й абсурду знаходимо у фільмі «Початок» («Inception»).

Як відмічають критики, у мистецтві метамодернізму спостерігається значний «могутній креативний вибух» що викликає неоднозначні оцінки дослідниками художніх творінь і їх значення щодо переосмислення цінностей культури, психологічного впливу на збагачення внутрішнього світу особистості й духовного життя суспільства.
За таких умов вирізняються «лідери» художнього універсуму, яскраві мистецькі зразки, які виступають певними «вузлами» на «мапі» докорінних перетворень, що відбуваються в духовному житті сучасної людини. Так, у зображальному мистецтві Д. Таррел створив світлові інсталяції, які зумовлюють виникнення змін у сприйнятті та навіть наявні сни. К. Енгман використовує дзеркало, фотографії, прості матеріали для створення об'єктів, котрі змінюють простір, а не порушують його, як це було у постмодернізмі. О. Еліассон створює світові та природні інсталяції, які вражають монументальністю, гармонійним суміщенням природного і штучного з одного боку, та зверненням до інтер'єру в дусі часів епохи Просвітництва і Ренесансу, - з іншого. Стилістичний дисонанс сприяє набуттю людиною нового досвіду - досвіду ірреальності, ясності, незрозумілого, міфічного.

Приклади літературного метамодернізму також свідчать про посилення інтересу авторів до психологізму й, відповідно, психологічної спрямованості художніх творів. Зокрема, для героїв роману Н. Тіммера «Нескінченний жарт» характерним $€$ суб'єктивний ідеалізм і навіть соліпсизм. Вони відчувають спустошеність у власному внутрішньому світі, свою самотність і відірваність від світу, відсутність емоційності та глибинних переживань, внутрішню закритість. Нерішучість як особистісна якість виникає у них у зв'язку з перевантаженням інформації, полісемії, різноманіття та багатовимірності світу, його деструкції та хаосоподібності, адже, коли дозволяється все, то можливим $є$ варіант «нічого», а отже, у героїв виникають проблеми із самовизначенням і прагнення розібратися у собі. Розчарування у цінностях і відсутність впевненості у світі й самовпевненості зумовлюють прояви нерішучості у виборі власних дій і пошуку нового життєвого шляху героя-протагоніста в автобіографічному романі Д. Керуака «У дорозі».

Аналітичний огляд особливостей мистецтва метамодернізму дозволяє відзначити психологічну спрямованість сучасної художньої творчості й диференціювати її за нижче наведеними рівнями.

Психофізіологічний рівень спрямованості метамодернізму передбачає активізацію психофізіологічних процесів, а також розкриття емоційних таємниць психоповедінки людей. Завдяки сенсорно-перцептивним і кінетичним діям у свідомості людини створюються суб'єктивні сенсорно-перцептивні образи та водночас усвідомлюються такі категорії, як художній простір, час, рух, колір, форма, фактура.

Серед провідних функцій психофізіологічного рівня спілкування з мистецтвом у науковій літературі вирізняється регуляція діяльності суб'єкта під впливом художніх цінностей мис- 
тецтва. Наприклад, у романі «Квіти Содому» Олеся Ульяненка виявляється причина всіх бід, яка, на думку одного з персонажів, криється в нейронах, які керують життям. «А потім гадаєш: чи то рецептори в голові разом з нейронами загуляли швидше, чи то якесь інше хитре паскудство?». Поєднання життєвих подій, психофізіологічних детермінант життя людини із ситуаціями, які неможливо пояснити з раціонального погляду, свідчить про виникнення «нового реалізму» як тотожного поняття метамодернізму.

У контексті розгляду психофізіологічного рівня психологічної спрямованості сучасного мистецтва варто згадати теорію перцептивних дій, що розвинута в ученні О.В. Запорожця, в положеннях якої наголошується на встановленні взаємозв'язку між діями аналізаторів у рухомому центрі мозку та зовнішнім простором при сприйнятті мистецтва. Так, у музикантів і танцівників завдяки руху відбувається перетворення біодинамічної тканини в чуттєву і здійснюється зворотний процес - чуттєва тканина образу трансформується в біодинамічну тканину руху. Прикладом цього перетворення $\epsilon$ танцювальна імпровізація у «вільному танці», танці-модерн і сучасних танцях - contemporary dance, хіп-хоп, брейк-данс).

Наведені приклади ілюструють дію психофізіологічного механізму чуттєвого відображення моторних ланок перцепції, тим самим слугують підтвердженням щодо особливостей сприймання таких перцептивних категорій, як ритм, жест, міміка. колір, світло, мелодія, гармонія, форма, фактура. Художньо-конструктивною домінантою цих категорій у всіх видах мистецтва виступає ритм. Види мистецтва відображають різними способами ритмічні закономірності навколишньої дійсності. Так, у кінематографі метамодернізму використовуються різні особливості ритму світла, передачі часу через рух, людського життя. Серед них: а) диско-фільми американського кінематографу «Saturday Night Fever» із композиціями групи «Bee Gees», «Thank Godls Friday» 3 хитами Донні Саммерс «Last Dance» та Дайани Росс «Lovin, Livin And Givin», «Can't Stop The Music» за участю «Village People»; б) брейк-фільми «Брейкінг», «Ритм вулиці» («Beat Street»), «Рознощики» («Delivery Boys» за участю легендарних груп «Dinamic Rockers» i «Incredible Breakers»).

Психофізіологічний вектор сучасної художньої творчості включає функціонування механізму, який виступає апаратом психологічного впливу за взаємодії різних видів мистецтв. Наявність цього апарату як основи виокремлення кінестетичного рівня у структурі особистості забезпечує подібність і спільність інтонаційних процесів у музиці, поезії, прозі, акторському мистецтві, активізує сприймання художніх творів, актуалізує процеси переживання та співпереживання. Тріада «образ почуття - думка» виступає внутрішньо неподільним змістовим комплексом інтонації. Це злиття містить у собі не тільки інформацію про психічний стан людського духу, душі та свідомості: в ньому «згорнуті» образні асоціації з рухом, жестом, мімікою, диханням, пульсом, фізичним і психічним тонусом. Тому інтонаційний зміст мистецтва, який чується й осмислюється людиною, впливає на всі шари її психіки - від рівня рефлексів й інстинктів до найвищих рівнів свідомості.

Стає очевидним, що психічне та фізичне начало в їх «зустрічному русі» організовується відповідно до внутрішньої логіки процесу інтонування. У цьому полягає пояснення їх єдності. Виступаючи як змістовий субстрат рухомого процесу, інтонація координує цей процес, формує рухому стратегію і тактику реципієнта, адже невипадково ситуацію, яка склалася в мистецтві метамодернізму, визначають як «зміну інтонацій».

В інтонаційному просторі мистецтв здійснюється взаємодія елементів різних художніх систем, що зумовлює перетворення потенційної енергії художнього розвитку людини в кінетичну, тобто в актуалізовані здатності особистості реагувати на процеси, які відбуваються у навколишній дійсності; відтворювати в мистецькій творчості інтонаційні будови життя; зберігати свою якісну визначеність, фіксуючи особливості взаємодії особистісного та соціального досвіду, що набуває специфічного відображення в мистецтві.

Конкретно-психологічний рівень спрямованості метамодернізму передбачає розширення свідомих і несвідомих актів у творчому процесі, заглиблення в ірраціональну та раціональну сфери особистості, активізацію психічних процесів і станів засобами мистецтва.

Науковий інтерес становить дія механізмів психологічного впливу на процеси творчого самовираження та самореалізації особистості; прояви самосвідомості в художній творчості.

У зв'язку з тим, що психологічний зміст мистецтва метамодернізму включає відображення психічних процесів і станів, психологічних метаморфоз і парадоксальних «зворотів» модальностей почуттів і думок, особливої значущості набуває здійснення системного аналізу мистецтва, в якому художній світ розглядається як “самосвідомість культури», ії конкретний стан. У цьому аспекті на увагу заслуговує дія психологічного механізму культурної самоідентифікації, функціонування якої дозволяє стверджувати про збереження людського «я», «самосвідомості культури» (М.С. Каган), культурної ідентичності суб'єкта мистецької діяльності. 
У художній творчості метамодернізму психологічним змістом і зверненням до культурної самоідентифікації наповнені навіть балетні вистави («Реквієм за Моцартом», «Мій Ієрусалим»), у яких передаються як найтонші нюанси психіки, так і драматичне напруження трагедії. Звернення до глибинних шарів самосвідомості людини спонукає митців до визначення нових векторів розвитку мистецтва, переосмислення його цінностей і призначення і, відповідно, до оновлення інтонацій, пластичних «фарб», образних ресурсів. Наприклад, серед танцювальних рухів психологічний інтерес викликають «мудрі рухи», самовираження яких свідчить про глибинні процеси самосвідомості виконавця, котрі визначають специфіку когнітивної ситуації в певну історичну епоху.

Психологічна спрямованість метамодернізму на свободу творчого самовираження митця передбачає деканонізацію виконання відмову від класичних канонів і норм, застарілих схем і стереотипів. Так, рухи артистів у сучасному танці $є$ більшим, ніж суто рухи: занурюючись у глибоко психологічний зміст композиції, такі рухи спонукають до загадковості, відходу від реалій навколишнього світу, поринання у власний внутрішній світ. у такий спосіб створюється подвійне прочитання художнього твору - митець інтерпретує як об'єктивну (зовнішню) реальність, так і реальність суб'єктивну (внутрішню). Інтерпретація бінарних опозицій піднесене / бридке та високе / низьке змінюються усвідомленням необхідності їх поєднання. Тож завдяки дії механізму культурної самоідентифікації, долається конфлікт між цими двома реальностями.

Нерідко стимулювання до осмислення духовних цінностей і смислу художніх творінь метамодернізму досягається прийомами провокації, емоційного й інтелектуального «шоку», що спрямовано на розширення сфери свідомості, прояви неусвідомлених реакцій реципієнтів.

Безперечно, вирішення нагальних проблем мистецтва метамодернізму, іноді навіт, незрозумілого, вимагає відкритого діалогу, адекватної системи художнього світогляду й образного мислення, інтелектуальної рефлексії, взаємоузгодження минулого, теперішнього та майбутнього. Наприклад, у сучасному мистецтві застосовується флешбек у минуле або флешфорвард у майбутнє, тимчасове переривання послідовності повідомлення з метою показу певних подій минулого або погляду в майбутнє. Флешбек використовують для пояснення вчинків героїв, розкриття їхніх задумів, ознайомлення аудиторії з попереднім перебігом аби запобігти труднощів у розумінні сюжету. Іноді весь твір $€$ неперервним ланцюжком флешбеків, зокрема у кінофільмі «Громадянин Кейн».
Нова драматургія метамодернізму передбачає художньо відображення психологічного стану, який виникає на межі між «тут і тепер», «вчора і потім», «розсіяного» сприймання художнього предмету або, навпаки, «аутичної» зосередженості на ньому. Іноді митці намагаються створити власні «утопічні» світи, художні простори, вибудовувати лабіринти Мінотавра, які наближені до нової щирості. За допомогою нових психологічних механізмів створюється нове мистецтво - «між надією та меланхолією, простодушністю й обізнаністю, емпатією й апатією, єдністю та множинністю, цільністю та розщепленням, ясністю та неоднозначністю» [6]. Метамодерністи прагнуть до мінливості, динамічності, нестабільності, єдності протилежностей.

Розкриваючи конкретно-психологічний рівень спрямованості метамодернізму, варто наголосити на намаганні митців поринути у сферу ірраціонального та неусвідомленого, звернутися до глибинних шарів підсвідомості. Для митця це не тільки джерело тривожності та психічного дискомфорту, а й можливість проявити власний творчий потенціал, культивувати езотеричну сферу взаємовідношень між власним свідомим і несвідомим (філософська драма Кальдерона «Життя і сон»).

При розгляді художніх форм прояву несвідомого інтерес викликає використання митцями феномена сновидінь, у яких спостерігається спільність із джерелами творчої уяви та фантазії. Засобами сновидінь сучасні митці прагнуть досягти зіткнення між двома реальностями - фізичною та метафізичною Існування сновидінь свідчить про те, що між «я» та реальністю існує певна межа, яка здатна або розширюватися, або звужуватися. І чим більш значущою $є$ ця межа, тим вона стає більш рельєфною, відбувається вихід підсвідомості 3-під контролю свідомості. Внаслідок подібної безконтрольності втрачається зв'язок між «я» та реальністю.

Яскравим прикладом використання в мистецтві метамодернізму прийому сновидінь для художнього відображення прояву процесів підсвідомості $€$ хореографічний триптих, поставлений Нідерландським театром танцю (Nederlands Dans Theater - NDT) на Міжнародному фестивалі сучасного танцю Montpellier Danse (2019 р.) в оперному театрі імені Г. Берліоза (Франція). Триптих включає різнохарактерні п'єси, назви яких вже свідчать про задум автора відобразити прояви підсвідомості, зокрема через сновидіння: 1) Shut Eye («Закрите око»); 2) Partita for 8 Dancers (Партіта для 8 танцівників); 3) Woke up Blind («Проснувся сліпим»).

У п'єсі Shut Eye («Закрите око») відображається витончений емоційний стан людини, яка перебуває у психічному стані між реальністю 
і сном. Містично завершується натхненне творіння, в якому втілено фантастичний світ сновидінь і мрій, сповнених чарівних пластичних новацій.

У хореографічній композиції Woke up Blind («Прокинувся сліпим») танцівники охоплені пристрастю, акустичним «всесвітом», високим мистецтвом протидіють вокальній силі гітари Дж. Бьоклі. Розкривається екзистенція людських емоцій завдяки використанню складних рухів на високому професійному рівні. Під ностальгічне звучання пісні «Ти і я» на чорному фоні з палаючою зіркою, починається дивертисмент, що складається із соло, дуетів і ансамблів, які вражають експресивними рухами тіла та специфічною жестикуляцією. У такий спосіб танцівники талановито створюють психологічну реальність, у якій заблукала людина, та ірреальність, у якій приховані глибини її підсвідомості. У фіналі артисти захоплюють глядача швидкою синхронною пульсацією та конвульсивною вібрацією кистей, що асоціюються з проявами галюцинацій. В останньому соло танцівник настільки віртуозно демонструє ритмічну жестикуляцію, що його рухи візуально зливаються в єдиний суцільний потік. Завдяки цьому прийому створюється сильне емоційне, навіть «шокове» враження. Йдучи зі сцени, танцівник на останок викрикує «Good night».

Зауважимо, що для розкриття психічних станів сучасної людини митцями використовуються методи хаосоподібності композиції та провокації, засоби візуалізації та механізми виникнення емоційного та інтелектуального “шоку». Так, у вокально-хореографічному дивертисменті Partita for 8 Dancers (Партіта для 8 танцівників), створеному в авангардному мистецтві (постановка Кристіал Пайт на музичну композицію Каролін Шоу), для досягнення ефекту візуалізації використовується психологічний механізм «через себе». Завдяки візуалізації рельєфної лінії «через себе» на фоні яскраво забарвленого полотна у вокально-хореографічному дивертисменті виникає загадкове враження та створюється додаткова динаміка розвитку хореографічних дій. Постановка насичена спеціальними ефектами: комп'ютерна проекція, гра світла, нові танцювальні рухи, які неначе виражають експресивний спів.

Аналізуючи соціально-психологічний рівень спрямованості мистецтва метамодернізму, слід звернути увагу на феномен «сучасності», тобто що саме вважати сучасним для суспільства і як провести розмежування між сучасністю та традицією. Безперечно, такий діалог свідчить про численні варіанти усвідомлення понять «сучасність» і «сучасне мистецтво», різні позиції в поглядах на проблему: «Яке мистецтво вважати сучасним?», «Чи можна вважати сучасним мистецтво, у змісті якого діє герой, вчинки якого близькі та знайомі аудито- рії?». Театральні реклами підтверджують актуальність роздумів на цю тему.

Міжнародний фестиваль «Контекст» продемонстрував публіці значний арсенал одноактних вистав мистецтва метамодернізму. У програму фестивалю включено три мистецькі заходи: Вечір Національного балету Канади, вечір молодих хореографів Context lab, вистава Охада Нааріна «Венесуела», а також освітня програма, до якої входять лабораторія танцювальної критики та майстер-класи. Так, увиставі «Венесуела» ізраїльського хореографа О. Нааріна, представленій на Міжнародному фестивалі «Контекст», розкривається власний погляд автора на проблему людини в сучасному суспільстві та використовується оригінальний спосіб ії передачі. У цій композиції показана людина у двох іпостасях: зовнішній, яка піддається раціональному осмисленню, та внутрішній, що характеризується розкриттям невідомих глибин людської сутності й наближається до медитативного усвідомлення.

За художнього відображення глибин підсвідомості ефективним засобом художньої виразності стає не хореографічний рух, а енергетична концентрація виконавця.

Висвітлюючи соціально-психологічний рівень спрямованості мистецтва, зауважимо, що останнім часом для художнього відображення соціальних стосунків між людьми реалізується ідея розвитку інстинкту соціальної організації комах. Для прикладу, у виставі «Виникнення» К. Пайт ідея метафоричного вираження людських стосунків, наближених до соціальної організації комах, відрізняється індивідуальною неповторністю. Сцена, яка нагадує підземний вулик, заповнюється «роєм» артистів, котрі створюють химерні візерунки і форми, доповнюючи таємничу атмосферу музичного супроводу, що інтригує аудиторію. Починаючи з музики, все, що відбувається на сцені, нагадує магічний процес.

У сучасному мистецтві настала епоха роздумів і міркувань над повсякденним життям звичайної людини. Численні мистецькі твори, які $€$ різними за змістом, стилем, драматургічним рішенням, об'єднує тема життєвого світу людини та її долі, що, відповідно, потребує нової аксіології та розкриття, пов'язаних із нею проблем сенсу життя, самовизначення людини, її самоцінності та життєвої нестабільності. У творчості метамодерністів домінує екзистенціальна проблематика та герой «соціально-екзистенціальний»і «соціально-онтологічний», який прагне подолати «бар'єри» долі, страх, самотність і занедбаність. Модель цього героя зорієнтована на пошуки самовизначення за нових умов соціуму, на відображення в ньому злиття особистого та загального.

Відображаючи екзистенціальну свідомість людини, митці показують абсурдність буття 
та жорстокість повсякденності життя, акцентуючи увагу на відчуженні особистості в дисгармонійному світі («Уйди-уйди» М. Коляди).

Філософсько-психологічний рівень спрямованості мистецтва метамодернізму має висхідну динаміку: мистецтво - модальна особистість - вплив особистості на художній твір (індивідуальне прочитання, виконавська інтерпретація, режисерська реконструкція) - онтологічна рефлексія. Модальність особистість розглядається не у самому мистецтві і не поза мистецтвом, а як психологічна реальність, що виявляє свої закономірності, котрі встановлюються у таких її параметрах, як: художня свідомість, творча уява, особистісні функції як система, що опосередковує вплив мистецтва; ціннісний тип переживання; естетичні стани та самовизначення як рефлексивна післядія мистецтва, в якій виражається духовна присутність особистості у відтворених формах світу художніх цінностей. 3 цих позицій здійснюється встановлення творчого зв'язку між внутрішньою енергією людини, мистецтвом і Всесвітом.

Отже, створення художніх зразків і цілісність інтерпретації мистецтва визначається суб'єкт-об'єктною єдністю людини та розгортанням її сутнісних сил у процесі онтологічної рефлексії. Прикладом філософсько-психологічного рівня психологічної спрямованості мистецтва метамодернізму є вистава «Буття та ніщо» на музику Ф. Гласса, поставлена Національним балетом Канади (постановка Гійома Коте), в якій переосмислюється однойменний філософський трактат Жана-Поля Сартра і постає проблема про смисл існування звичайної людини та пошук нею ціннісних орієнтирів у повсякденному житті. Канадський балет пропонує нове рішення змісту цієї проблематики: контрапунктом до розгорнутих танцювальних епізодів, які відображають побутовий аспект життєвих ситуацій, є чоловічий кордебалет, котрий виступає в сірих костюмах, що символізує «ніщо», очевидно, смерть. У такий спосіб істотно збільшується ступінь узагальнення поставленої проблеми, надається їй певний філософський смисл. Задум автора, очевидно, свідчить про його намагання показати, що життя домінує над роздумами й судженнями про «ніщо». Психологічний інтерес викликає остання частина спектаклю «Виклик», де внаслідок телефонного дзвінка у внутрішньому світі героїні (Грети Ходжинсон) розгорається ціла гама переживань, зміна емоційних станів, яка художньо передається автором завдяки власній «внутрішній» драматургії та виразній хореографії.

Зазначимо, що нині виокремлюється покоління драматургів, які готові до діалогу щодо цінностей і самобутності метамодернізму, до відстоювання паратеатральних форм мистецтва, до спроби «експлікації» естетичної логіки сучас- ного європейського театру в межах нової художньої концепції. Тут варто навести сюжет п'єси «Подвиг» О. Потапової (режисер В. Левицький), у якому повідомляється про життя речей і людей. Створена як педантична фіксація звуку від банківського автомату до стукоту коліс метро, ця п'єса нагадує експерименти А.Г. Наймана в музичному мистецтві. У тексті $є$ фабула із зупиненням поїзду героєм, міститься вираження шумового багатоголосся повсякденного життя, яке подається у виді репетиції оркестру, де кожний актор - це музичний інструмент, який налагоджує своє звучання.

Висновки 3 проведеного дослідження. Психологічна спрямованість мистецтва метамодернізму передбачає активізацію психологічних аспектів життя сучасної людини, а саме: розвиток трансцендентного та іманентного начал у внутрішньому світі особистості; поєднання раціонально-логічного та ірраціонально-чуттєвого рівнів свідомості; розширення сфери свідомості й актуалізацію несвідомих (неусвідомлених) процесів; розкриття «граничних» психологічних станів особистості, що виникають на межі раціонального та ірраціонального; злиття в художніх уявленнях реальної та нереальної дійсності; досягнення творчої свободи самовираження; спонукання до розуміння смислу життя та перетворення існуючої соціокультурної дійсності.

Психологічні виміри розвитку художньої творчості метамодернізму дозволяють виокремити рівні ї̈ психологічної спрямованості: психофізіологічний; конкретно-психологічний; соціально-психологічний; філософсько-психологічний. Завдяки взаємодії цих рівнів у сучасному мистецтві здійснюється поєднання індивідуально-особистісної та соціально-загальної сфер, досягається інтегрована взаємодія художніх способів сприйняття мистецтва. Полімодальність мистецтва метамодернізму спонукає до рефлексивного заглиблення в життєві ситуації, переосмислення духовних цінностей мистецтва, подолання кризової ситуації в соціокультурній дійсності, встановлення суб'єкт-об'єктної єдності в системі «особистість - мистецтво - Всесвіт».

\section{ЛІТЕРАТУРА:}

1. Бакіров Д.Р. Християнський метамодернізм. URL: http://medium.com/@denysbakirov/християнський-метамодернізм-аe773eda7817.

2. Ван ден Аккер Робин. Метамодернизм. Историчность. Асрфект и глубина после постмодернизма / перевод В.М. Липса. Изд-во Рипол-Классик, 2019. URL: http:// labirint.ru/books/715488.

3. Дроздовський Д. Постмодернізм помер. Хай живе пост-постмодернізм! URL: http://litakcent. com/2013/05/17postmodernizm-pomer-haj-zhyve- postpostmodernizm.

4. Тёрнер Л. Манифест метамодерниста. URL: metamodernizm.org. 